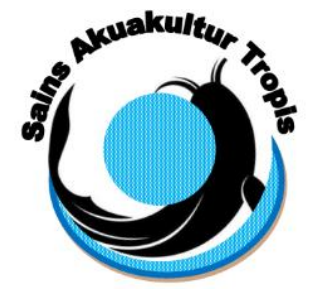

\author{
Jurnal Sains Akuakultur Tropis \\ Departemen Akuakultur \\ Fakultas Perikanan dan IImu Kelautan - Universitas Diponegoro \\ Jl. Prof. Soedarto, SH, Tembalang, Semarang 50275 \\ Telp. (024) 7474698, Fax.: (024) 7474698 \\ Email: sainsakuakulturtropis@gmail.com, sainsakuakulturtropis@undip.ac.id
}

\title{
EVALUASI KELAYAKAN USAHA BUDIDAYA IKAN BANDENG (Chanos chanos) SECARA SEMI INTENSIF DI KECAMATAN ULUJAMI, KABUPATEN PEMALANG
}

\author{
Evaluation of Business Feasibility of Milkfish Cultivation (Chanos chanos) in Semi Intensive Method at Ulujami \\ District, District Pemalang
}

\author{
Rizky Handayani, Sri Rejeki*), Tita Elfitasari \\ Departemen Akuakultur, \\ Fakultas Perikanan dan Ilmu Kelautan, \\ * Corresponding author: sri_rejeki7356@yahoo.co.uk
}

J1. Prof. Soedarto, SH, Tembalang, Semarang, Jawa Tengah -50275, Telp/Fax. +62247474698

\begin{abstract}
ABSTRAK
Bandeng merupakan salah satu jenis ikan konsumsi yang paling banyak dibudidayakan di Indonesia. Berkembangnya teknologi budidaya bandeng di masyarakat, tidak terlepas dari keunggulan komparatif dan strategisnya karena dapat dibudidayakan di air payau, laut bahkan air tawar serta toleran terhadap perubahan mutu lingkungan. Teknologi pembesaran dan pembenihannya telah dikuasai masyarakat. Ikan bandeng tahan terhadap serangan penyakit. Prospek dari pengembangan usaha pembesaran ikan bandeng di Kecamatan Ulujami memiliki potesi yang baik karena tingginya permintaan pasar. Tujuan dari penelitian ini adalah untuk mengetahui aspek teknis, aspek finansial, serta kelayakan usaha budidaya ikan bandeng di Kecamatan Ulujami. Metode yang digunakan pada penelitian ini adalah metode wawancara yaitu dengan menggunakan kuisioner untuk pengambilan data. Jumlah responden yang diambil untuk penelitian ini ada 6 responden, dengan setiap desa terdiri dari 2 responden. Permasalahan yang muncul pada usaha budidaya pembesaran bandeng adalah bagaimana upaya untuk memperoleh hasil yang baik dan menguntungkan dalam memenuhi keinginan masyarakat dengan mengeluarkan biaya sekecil mungkin karena hal tersebut berpengaruh terhadap profitabilitas dari pendapatan pembudidaya bandeng tersebut. Analisis data berdasarkan nilai dari Payback Period (PP) yang terdapat di Desa Limbangan yaitu: 0.34; Desa Mojo: 0.98 dan Desa Pesantren: 5.85. Net Present Value (NPV) hasil NPV para petani tersebut bernilai positif. Benefit Cost Rasio (B/C Rasio) masing-masing desa adalah 2.35. Hasil dan kesimpulan yang diperoleh berdasarakan aspek teknis pemilihan lokasi, tempat pemeliharaan, proses pemeliharaan, pemanenan bandeng dan aspek finansial kelayakan usaha ialah dikatakan layak untuk dilakukan.
\end{abstract}

Kata kunci: Evaluasi, Usaha, Budidaya, Bandeng, Ulujami

\section{ABSTRACT}

Milkfish is one of the most widely cultivated fish species in Indonesia. The development of milkfish cultivation technology in the community is inseparable from its comparative and strategic advantages because milkfish can be cultivated in brackish water, sea water and even freshwater and tolerant to environmental quality changes. Technology of cultivation and seeding has been done by the community. Milkfish is not susceptible to disease. The prospect of the development of milkfish breeding business in Ulujami District has good potential due to market demand. The purpose of this research is to know the technical aspect, financial aspect, and business feasibility of milkfish cultivation in Ulujami District. This research method is interview that is using questionnaire for data retrieval. The number of respondents taken for this research is 6. Any village consists of 2 respondents. The problems that arise in the breeding business of milkfish enlargement is how the efforts to obtain good and profitable results in fulfilling the market demand by spending as less as possible because it affects the profitability of the milkfish farmer income. Data analysis methods are obtained from Payback Period (PP), which is located in Limbangan Village 0.34, Mojo Village 0.98 and Pesantren Village 5.85. Net Present Value (NPV), the farmer's NPV value is positiv. Benefit Cost Ratio (B / C Ratio) of each village are 2.35. Results and conclusions are obtained based on the technical aspects of site selection, maintenance, milkfish harvesting and financial aspects of business feasibility it this worth to be.

Keywords: Evaluation, Business, Culture, Milkfish, Ulujami

Article Received: 24-07-2018; Accepted: 10-01-2019 


\section{PENDAHULUAN}

Kabupaten Pemalang merupakan salah satu tempat budidaya ikan bandeng (Chanos chanos) memiliki kualitas yang bagus, bahkan bahan utama ikan dari produk ternama Bandeng Juwana berasal dari Kabupaten Pemalang. Nilai panen yang cukup tinggi tercatat di tahun 2015 mencapai 8.261 ton, menjadikan potensi bandeng ini adalah salah satu budidaya perikanan yang banyak diminati petani tambak untuk dikembangkan berkelanjutan. Besarnya kapasitas produksi panen belum bisa dimanfaatkan untuk dijual dalam bentuk olahan, agar memiliki nilai jual yang tinggi. Saat ini hanya beberapa kecil pelaku UKM saja yang sudah mulai mengembangkannya menjadi makanan olahan. Kecamatan Ulujami merupakan salah satu wilayah di Kabupaten Pemalang yang memiliki kawasan pantai dan laut yang prospektif untuk dikembangkan sebagai sentra industri perikanan khususnya budidaya ikan bandeng. Dengan potensi areal yang ada, evaluasi kelayakan bisnis budidaya bandeng merupakan kegiatan yang sangat relevan untuk dilakukan. Penggunaan pakan yang efisien, untuk tingkat kematian yang sangat rendah juga dipengaruhi dari kualitas benih (nener) bandeng yang baik. Kebanyakan pembudidaya bandeng mengambil benih dari pendeder, ada juga yang membesarkan sendiri dari nener sampai ukuran benih siap tebar di kolam pembesaran. Harga bandeng relatif tinggi, yaitu Rp 15.000 - Rp 20.000 per kilogram untuk ukuran 3 ekor/kilogram.

Bandeng merupakan salah satu jenis ikan laut konsumsi yang paling banyak di budidayakan di Indonesia. Berkembangnya teknologi budidaya bandeng di masyarakat, tidak terlepas dari keunggulan komparatif dan strategisnya karena dapat dibudidayakan di air payau, laut, air tawar, toleran terhadap perubahan mutu lingkungan, teknologi pembesaran dan pembenihannya telah dikuasai masyarakat, serta tahan terhadap serangan penyakit. Selain itu, bandeng digunakan sebagai umpan hidup dalam penangkapan tuna dan cakalang, dan telah pula menjadi komoditas ekspor (Kordi, 2009). Keunggulan bandeng sebagai komoditas budidaya adalah dapat tumbuh dengan baik, dapat dipanen dua kali dalam setahun, dapat dibudidayakan dengan sistem polikultur bersama jenis ikan lain, udang dan rumput laut, harga jualnya relatif stabil dan produknya dapat segera diserap pasar. Bahkan ada juga pembudidaya yang bekerjasama dengan pabrik pengolahan ikan. Sebagian besar bandeng dipasarkan dalam bentuk presto dan atau bandeng asap. Modifikasi olahan bandeng juga terus dilakukan, antara lain dalam bentuk olahan bandeng tanpa duri, otak-otak bandeng dan bandeng crispy (di fillet dan digoreng kering). Penelitian ini dilakukan dengan pendekatan pada aspek teknis, aspek ekonomis. Aspek teknis meliputi cara budidaya yang dilakukan oleh petani, seperti persiapan lahan, penebaran benih, pemberian pakan, pemanenan, pemasaran dan kegiatan budidaya lainnya yang berkaitan dengan aspek teknis.

Penelitian ini bertujuan untuk mengetahui evaluasi kelayakan usaha budidaya ikan bandeng (Chanos chanos) secara semi intensif di Kecamatan Ulujami, Kabupaten Pemalang dan juga mengetahui padat tebar benih ikan bandeng. Budidaya semi intensif merupakan perbaikan dari pola ekstensif sehingga sering disebut pola ekstensif yang diperbaiki. Penerapan pola semi intensif dicirikan dari beberapa faktor yaitu petak tambak pemeliharaan ikan lebih kecil dibandingkan pada pengelolaan ekstensif; padat penebaran lebih tinggi, pada ikan bandeng antara 1-2 ekor/ $\mathrm{m}^{2}$; kegiatan pengelolaan wadah pemeliharaan semakin banyak. Pentingnya evaluasi kelayakan usaha ialah mengevaluasi dan mengembangkan pembesaran ikan bandeng. Target sasaran penelitian ini juga untuk mengoptimalkan sumber daya alam yang ada, sehingga pembesaran ikan bandeng (Chanos chanos) berjalan secara sustainable dan dapat meningkatkan taraf hidup masyarakat. Penelitian ini dilaksanakan pada bulan Maret 2017 di Kecamatan Ulujami, Kabupaten Pemalang.

Usaha budidaya ikan bandeng memiliki keuntungan, baik dikembangkan dalam bidang pembesaran maupun pembenihan. Minat masyarakat terhadap ikan bandeng semakin bertambah. Dengan menerapkan metode pemeliharaan yang baik, maka akan menghasilkan produk budidaya yang sesuai dengan keinginan masyarakat. Berbagai penelitian terhadap evaluasi kelayakan usaha budidaya bandeng dilakukan untuk memenuhi keinginan masyarakat dengan biaya sekecil mungkin khususnya di desa Limbangan, Kabupaten Pemalang.Perbaikan profit secara finansial perlu dilakukan dengan perhitungan keuangan, permodalan, pembiayaan dan pendapatan dalam periode waktu tertentu. Sedangkan aspek ekonomi dalam usaha dapat ditentukan berdasarkan perhitungan Benefit Cost Ratio (B/C Ratio). Variabel yang diamati dalam usaha pembesaran budidaya bandeng adalah bibit, pakan, tenaga kerja, listrik, transportasi, perawatan aset, perizinan, pupuk dan obat-obatan. Tujuan penelitian ialah untuk mengetahui aspek teknis pembesaran bandeng dan untuk mengetahui aspek finansial pembesaran ikan bandeng di Kecamatan Ulujami, Kabupaten Pemalang.

\section{MATERI DAN METODE}

Metode yang digunakan dalam penelitian ini adalah studi kasus. Penelitian studi kasus merupakan penelitian dimana peneliti mengamati suatu peristiwa, aktivitas, proses, atau sekelompok individu dan peneliti mengumpulkan informasi secara lengkap dengan menggunakan berbagai prosedur pengumpulan data berdasarkan waktu yang telah di tentukan (Cresswell, 2008).

Lokasi penilitian ini dilakukan di Kecamatan Ulujami, Kabupaten Pemalang. Dari 8 desa yang ada di Kecamatan Ulujami dipilih tiga desa yaitu Desa Pesantren, Desa Mojo dan Desa Limbangan. Ketiga desa tersebut yang dianggap memenuhi kriteria dengan jumlah luas lahan tertinggi dan memiliki tingkat pembudiayaan ikan bandeng yang tinggi. Luas lahan tertinggi dijadikan kriteria pemilihan karena dapat memberikan potensi yang 
lebih terhadap pembudiayaan ikan. Dipilihnya 3 desa tersebut karena sebagian besar penduduknya masih aktif membudidayakan ikan bandeng dapat dilihat pada data lampiran 4.

Dalam penelitian ini dilakukan di 3 desa pada Kecamatan Ulujami, Kabupaten Pemalang pada setiap desa dipilih 2 responden yang dianggap memiliki kelayakan paling baik, karena para responden tersebut memiliki hasil budidaya yang baik dan memiliki keuntungan yang cukup tinggi. Keenam responden yang dipilih pada setiap desa yakni petani tambak ikan bandeng di Desa Pesantren milik bapak Johar dan bapak Sofian, Desa Mojo milik bapak Adil dan bapak Rasdi, Desa Limbangan milik bapak Cariwan dan bapak Kusnadi.

\section{Pengumpulan Data}

Metode yang digunakan dalam pengambilan data pada penelitian ini adalah:

1. Observasi langsung

Observasi adalah studi yang disengaja dan sistematis tentang fenomena sosial dan gejala-gejala psikis dengan jalan pengamatan dan pencatatan

Observasi yang dilakukan diantara lain pemilihan lokasi dan pemilihan responden. Lokasi penelitian dilakukan di Kecamatan Ulujami, Kabupaten Pemalang. Dipilih lokasi tersebut karena masih aktif melakukan kegiatan budidaya pembesaran ikan bandeng.

\section{Wawancara}

Wawancara adalah percakapan dengan maksud tertentu. Percakapan dilakukan oleh dua pihak, yaitu pewawancara yang mengajukan pertanyaan dan yang diwawancarai yang memberikan jawaban atas pertanyaan itu.

Tujuan dari wawancara ini adalah untuk menemukan permasalahan lebih terbuka, dimana pihak yang diajak wawancara diminta pendapat, tentang pengalamannya terkait dengan budidaya pembesaran bandeng di Kecamatan Ulujami, Kabupaten Pemalang.

\section{Kuisioner}

Kuesioner adalah teknik pengumpulan data melalui formulir-formulir yang berisi pertanyaan-pertanyaan yang diajukan secara tertulis pada seseorang atau sekumpulan orang untuk mendapatkan jawaban atau tanggapan dan informasi yang diperlukan oleh peneliti (Mardalis, 2008). Penelitian ini menggunakan kuisioner, daftar pertanyaannya dibuat secara berstruktur dengan bentuk pertanyaan terbuka. Wawancara dilakukan secara langsung dengan petani budidaya pembesaran bandeng dan aspek ekonominya di Kecamatan Ulujami, Kabupaten Pemalang.

\section{Dokumentasi}

Metode dokumentasi yaitu pengumpulan data dimana peneliti menyelidiki dengan cara pengambilan gambar (Arikunto, 2002).

\section{Metode Analisis Data \\ Evaluasi Kelayakan Usaha}

Data yang mencakup kelayakan usaha meliputi:

Biaya investasi/modal yang dikeluarkan oleh unit usaha pembesaran ikan bandeng yang meliputi pembuatan tambak, wadah budidaya, induk, dan sarana produksi lainnya, biaya tetap ialah biaya yang tidak ada kaitannya dengan jumlah barang yang produksi. Biaya tetap seperti mesin, perahu, dan alat-alat lainnya. Sedangkan biaya operasial seperti biaya perawatan (alat yang digunakan dilapangan), biaya tenaga kerja, biaya transportasi dan biaya listrik. Penerimaan / pendapatan yaitu nilai produksi dari penjualan hasil budidaya per siklus yang kemudian dikalikan dengan biaya banyaknya siklus selama satu tahun dan keuntungan yang diperoleh dari pengurangan penerimaan dengan biaya total yang dihitung selama satu tahun.

Lokasi pembudidayaan ikan bandeng terletak di Desa Pesantren, Desa Mojo dan Desa Limbangan, Kecamatan Ulujami, Kabupaten Pemalang dimana masing-masing desa terdiri dari 2 responden. Batas-batas wilayah desa ini yaitu sebelah timur berbatasan dengan Sungai Comal, Desa Mojo, dan Desa Limbangan. Luas tambak yang dimiliki oleh responden yaitu sekitar 3 hektar. Status kepemilikan lahan adalah milik pribadi. Di sekitar tambak dikelilingi oleh pohon mangrove yang tertata rapi.

Responden kedua berasal dari Desa Mojo. Desa Mojo terletak bersebelahan dengan Desa Pesantren, Desa Mojo adalah sebuah desa yang terletak di pesisir pantai utara Jawa di Kabupaten Pemalang. Luas tambak yang digunakan seluas 1.5 ha dimana status kepemilikan tambak adalah milik pribadi. Sekeliling tambak dikelilingi pohon mangrove. Responden ketiga berasal dari Desa Limbangan. Tambak yang dimiliki responden adalah seluas 2 ha dan status kepemilikannya merupakan tambak milik pribadi. Kondisi sekeliling tambak adalah pohon mangrove.

\section{Analisis Kelayakan Usaha}

Metode yang digunakan untuk melakukan analisis kelayakan usaha dalam penelitian ini adalah: 


\section{a. Payback Period (PP)}

Payback Period atau masa pembayaran kembali adalah suatu jangka waktu (periode) kembalinya keseluruhan jumlah investasi yang ditanamkan, dihitung mulai dari permulaan proyek sampai dengan arus netto produksi tambahan, sehingga mencapai jumlah keseluruhan investasi modal yang ditanamkan dengan menggunakan aliran kas. Menurut Umar (2003), secara matematis payback period dapat dirumuskan sebagai berikut:

$$
\text { PP } \frac{\text { investasi }}{\text { keuntungan }}
$$

Kriteria yang digunakan adalah sebagai berikut:

- $\quad \mathrm{PP}<5$ tahun, berarti usaha mempunyai PP yang cepat sehingga layak untuk diusahakan

- $\quad \mathrm{PP}>5$ tahun, berarti usaha mempunyai PP yang lambat sehingga kurang layak untuk diusahakan

b. Net Present Value (NPV)

Net Present Value merupakan manfaat bersih yang diterima selama umur proyek. Perhitungan NPV adalah sebagai berikut (Gittinger, 1986):

$$
\mathrm{NPV}=\sum_{\mathrm{t}=1}^{\mathrm{n}} \frac{C F t}{(1+\mathrm{i}) t}-C o
$$

Dengan kriteria:

- $\quad$ NPV $>0 \rightarrow$ maka secara finansial usaha layak untuk dilaksanakan karena manfaat yang diperoleh lebih besar dari biaya

- $\quad$ NPV $<0 \rightarrow$ maka secara finansial usaha tersebut tidak layak untuk dilaksanakan, karena manfaat yang diperoleh lebih kecil dari biaya yang dikeluarkan

- $\quad \mathrm{NPV}=0 \rightarrow$ maka secara finansial usaha tidak menguntungkan dan juga tidak rugi, karena manfaat yang diperoleh hanya cukup untuk untuk menutupi biaya yang dikeluarkan.

\section{c. Benefit Cost Ratio (B/C Ratio)}

Menurut Kadariah et al (1999) Net Benefit Cost Ratio adalah besarnya manfaat tambahan pada setiap tambahan biaya sebesar satu satuan waktu. Net B/C merupakan perbandingan antara nilai sekarang (present value) dari net benefit bernilai positif dengan net benefit bernilai negatif. Rumus yang digunakan adalah sebagai berikut:

$$
\mathrm{B} / \mathrm{C} \text { Ratio }=\frac{\text { penerimaan }}{\text { biaya total }}
$$

Pengambilan kesimpulan:

- $\quad$ B/C Ratio > 1: berarti usaha tersebut layak atau menguntungkan

- $\quad \mathrm{B} / \mathrm{C}$ Ratio < 1: berarti usaha tersebut tidak layak atau tidak menguntungkan

\section{HASII}

\section{Aspek Teknis}

Aspek teknis yang berkaitan dengan kegiatan budidaya ikan bandeng di Kecamatan Ulujami, Kabupaten Pemalang antara lain pemilihan lokasi budidaya, proses pemeliharaan, tempat pemeliharaan, pemanenan bandeng serta pemanenan yang dilakukan oleh para petani bandeng tersebut.

a. Proses Pemeliharaan

Proses pemeliharaan budidaya ikan bandeng dari nener dengan ukuran panjang $2 \mathrm{~cm}$ yang dimasukkan ke dalam wadah. Kemudian benih ikan tersebut dipilih bibit yang layak untuk di budidayakan. Setelah benih berusia 1 bulan dilepaskan kedalam tambak dan kolam dibersihkan dengan menggunakan jaring untuk menangkap predator atau ikan - ikan yang memakan bibit bandeng, agar nener tersebut aman.

b. Tempat Pemeliharaan

Tempat pemeliharaan budidaya ikan bandeng berupa tambak dengan ukuran $1.5-3$ hektar. Pencangkulan dan pembalikan tanah. Bertujuan untuk membebaskan senyawa dan gas beracun sisa budidaya hasil dekomposisi bahan organik baik dari pakan maupun dari kotoran. Selain itu dengan menjadi gemburnya tanah, aerasi akan berjalan dengan baik sehingga kesuburan lahan akan meningkat.

Pemupukan fungsi utama pemupukan adalah memberikan unsur hara yang diperlukan bagi pertumbuhan pakan alami, memperbaiki struktur tanah dan menghambat peresapan air pada tanah-tanah yang tidak kedap air (porous). Penggunaan pupuk untuk pemupukan tanah dasar kolam sangat tepat, karena pupuk mengandung unsurunsur mineral penting, dan asam-asam organik utama memberikan bahan-bahan yang diperlukan untuk peningkatan kesuburan lahan dan pertumbuhan plankton. Dosis pemupukan adalah 5 botol/ha atau 25 gr/100 m2. 
Pengelolaan air setelah dilakukan pemupukan, air dimasukkan hingga setinggi $10-20 \mathrm{~cm}$ kemudian dibiarkan beberapa hari, untuk menumbuhkan bibit-bibit plankton. Air dimasukkan hingga setinggi $80 \mathrm{~cm}$ atau menyesuaikan dengan kedalaman kolam.

Desa Mojo seluas 2.5 ha di masukkan benih sebanyak 30.000 ekor yang dibeli dari tengkulak dengan harga Rp 100 - 140/ekor. Pemberian pakan dilakukan 2 kali sehari dengan pakan pellet dan pakan buatan berupa roti yang sudah lama dihancurkan. Harga pakan per karung sebesar Rp 200.000,00 - Rp. 215.000,00. Pemeliharaan benih sampai panen 3 bulan. Tambak yang digunakan berstatus lahan milik pribadi.

Sedangkan di Desa Pesantren seluas 3 ha di masukkan benih sebanayak 12.000 - 14.000 ekor yang dibeli dari tengkulak dengan harga Rp 100 - 175/ekor. Pemberian pakan dilakukan 2 kali sehari dengan pakan pellet. Harga pakan per karung sebesar Rp 215.000,00. Pemeliharaan benih sampai panen 3 bulan. Tambak yang digunakan berstatus lahan milik pribadi. Tambak yang digunakan berstatus lahan milik pribadi.

Di Desa Limbangan seluas 2 ha, dimasukkan benih sebanyak 15.000 ekor yang dibeli dari tengkulak dengan harga Rp 140/ekor. Pemberian pakan dilakukan 2 kali sehari dengan pakan pellet. Harga pakan per karung sebesar Rp 210.000,00. Pemeliharaan benih sampai panen 3 bulan. Tambak yang digunakan berstatus lahan milik pribadi.

c. Pemanenan bandeng

Secara umum pemanenan ikan hasil pembesaran sama seperti pemanenan lainnya yang dilakukan setelah bobot ikan memenuhi permintaan pasar. Cara pemanenan dilakukan dengan cara air tambak di buang melalui pintu air dengan bantuan pompa air sampai pelataran kelihatan. Bandeng dipanen dengan menggunakan alatberupa jaring khusus yang dibuat untuk memanen bandeng, kemudian air di tambak dibuang melalui pintu air dengan bantuan pompa air. Setelah air surut biasanya dilakukan pendorongan ke arah waring/wadong dengan menggunakan bantuan karung yang berisi rumput. Hasil bandeng yang dipanen dalam satu siklus dengan padat tebar $14.000-20.000$ ekor dalam tambak seluas $1.5-2$ ha adalah sebanyak 2 ton. Harga jual ikan bandeng dari tengkulak Rp.15.000/kg dengan isi 3 ekor.

\section{Aspek Finansial Kelayakan Usaha}

Aspek finansial pada budidaya ikan bandeng di Kecamatan Ulujami, Kabupaten Pemalang yang meliputi biaya investasi, operasional dan pendatan para petani dapat dilihat pada tabel 1 .

Tabel 1. Rata-rata biaya Investasi, biaya operasional dan pendapatan (Jumlah Siklus 2 kali/tahun)

\begin{tabular}{llll}
\hline \multicolumn{1}{c}{ Nama Desa } & \multicolumn{1}{c}{ Biaya Investasi } & Biaya Operasional & Pendapatan \\
\hline 1. Desa Limbangan & Rp. 14.000 .000 & Rp. 32.360 .000 & Rp. 70.000 .000 \\
2. Desa Mojo & Rp. 9.850 .000 & Rp. 48.400 .000 & Rp. 66.000 .000 \\
3. Desa Pesantren & Rp. 16.800 .000 & Rp. 72.560 .000 & Rp. 98.000 .000 \\
\hline
\end{tabular}

Berdasarkan hasil penelitian, biaya investasi pada Desa Limbangan dengan Bapak Cariwan sebesar Rp. 15.000.000 dan Bapak Kusnadi sebesar Rp. 13.000.000. Bapak Adil dari Desa Mojo Rp. 9.700.000 dan Bapak Rasdi sebesar Rp. 10.000.000 sedangkan Desa Pesantren dengan Bapak Johar Rp. 25.000.000 dan Bapak Sofian sebesar Rp. 8.600.000 . Biaya tersebut meliputi sewa lahan, perbaikan tambak dan biosecurity. Biaya operasional pada Desa Limbangan dengan Bapak Cariwan Rp. 33.820 .000 dan Bapak Kusnadi Rp. 30.900.000. Desa Mojo dengan bapak Adil Rp. 42.000.000 dan Bapak Rasdi Rp. 54.700.000. Desa Pesantren dengan Bapak Johar Rp. 92.120.000 dan Bapak Sofian Rp. 53.000.000. Biaya operasional tersebut meliputi pakan, pupuk, benih, perawatan tambak dan gaji pegawai. Pendapatan yang didapat oleh Bapak Cariwan dan Bapak Kusnadi dari Desa Limbangan sebesar Rp. 80.000.000 dan Rp. 60.000.000 Bapak Adil dan Bapak Rasdi dari Desa Mojo Rp. 60.000.000 dan Rp. 72.000.000. Bapak Johar dan Bapak Sofian dari Desa Pesantren sebesar Rp. 120.000.000 dan Rp. 76.000.000.

Nilai NPV, B/C Ratio dan Payback Periode dapat dilihat pada Tabel 2. 
Tabel 2. NPV, IRR, B/C Ratio dan Payback Periode

\begin{tabular}{lccc}
\hline Responden & NPV & B/C Ratio & Payback Periode \\
\hline $\begin{array}{l}\text { Desa Mojo } \\
1\end{array}$ & 277.903 .367 & 1,588579505 & 1,08 \\
2 & 437.551 .778 & 0,1776156 & 0,28 \\
\hline Desa Limbangan & & & 0,34 \\
3 & & 1,665947298 & 0,34 \\
4 & 208.485 .450 & 1,293068786 & \\
\hline Desa Pesantren & 88.655 .800 & & 0,27 \\
5 & & 0,213122841 & 0,21 \\
6 & 696.894 .189 & 0,336508022 & \\
\hline
\end{tabular}

Hasil analisis finansial kedua pokdakan tersebut dapat diketahui bahwa usaha budidaya pembesaran ikan bandeng di Kecamatan Ulujami Kabupaten Pemalang masih layak dijalankan. Dikatakan layak karena dari hasil budidaya ikan bandeng yang dihasilkan cukup baik. Untuk itu bisnis ini masih mempunyai prospek untuk dikembangkan. Berdasarkan hasil NPV para petani tersebut bernilai positif, hal ini menunjukkan usaha budidaya layak untuk diteruskan.

\section{PEMBAHASAN}

\section{Aspek teknis}

a. Pemilihan Lokasi

Tambak merupakan salah satu wadah yang dapat digunakan untuk membudidayakan ikan air payau atau laut. Letak tambak biasanya berada di sepanjang pantai dan mempunyai luas berkisar antara 0,3 - 2 ha. Luas petak tambak sangat bergantung kepada sistem budidaya yang diterapkan. Bentuk dan konstruksi tambak bandeng relatif sama dengan kolam di air tawar. Perbedaan keduanya adalah jenis air yang digunakan, yaitu kolam menggunakan air tawar sedangkan tambak menggunakan air payau atau laut.

Pemilihan lokasi merupakan hal yang paling penting dalam pembuatan tambak. Kesalahan dalam menentukan lokasi tambak mengakibatkan kerugian tidak hanya biaya dan tenaga tetapi juga kerugian waktu. Contoh kasus akibat kesalahan pemilihan lokasi, yaitu tidak berproduksi suatu tambak setelah dibangun karena tidak dapat di airi, sulit mendapatkan sarana produksi atau sulit mendapatkan tenaga kerja. Lokasi pertambakan hendaknya harus baik dalam pemilihan letak lokasinya yaitu dalam pemilihan lokasinya terletak di tepi jalaan dan mudah di jangkau serta tidak terlalu jauh dari pemukiman penduduk, Ditjenkan (1994).

\section{b. Proses Pemeliharaan}

Setelah nener mencapai ukuran gelondongan, serta pakan alami sudah tumbuh di tambak. Lakukan penebaran dengan kepadatan sekitar $7.500-10.000$ untuk gelondongan $10 \mathrm{~cm}$, dengan target panen lebih 1 ton/ha. Dimana biasanya target 1 hektar menghasilkan 1 ton bandeng, dengan daya hidup $90 \%$ dan berat 200 gram/ekor. Produksi dapat mencapai 1,5 ton apabila pakan alami tersedia dengan lama pemeliharaan 5 - 6 bulan. Tebarlah benih bandeng gelondongan yang memiliki ukuran seragam. Waktu penebaran dilakukan pada pagi atau sore hari. Jika kondisi perairan tambak baik dan pakan alami cukup, maka dengan pemeliharaan selama 3 - 4 bulan di petak pembesaran, maka ikan bandeng dapat mencapai ukuran 300 - 350 g/ekor (3 ekor/kg) (Tristian, 2011).

\section{c. Tempat Pemeliharaan}

Tambak yang sudah dipersiapkan akan dilakukan pengurasan air dan penaikkan lumpur. Lumpur diletakkan pada sisa-sisa tanggul. Hal ini dilakukan untuk menutup kemungkinan adanya lubang-lubang pembesaran sekaligus untuk memperbaiki tanggul. Setelah lumpur diangkat, pembalikan tanah dasar tambak atau digemburkan dengan mengunakan cangkul, hal ini dilakukan untuk menyempurnakan proses oksidasi pada tanah. Setelah itu dilakukan pengeringan selama 10 - 15 hari.

Pengeringan lahan bertujuan agar gas-gas sisa metabolit menguap. Selama proses pengeringan dilakukan perbaikan pintu dan pemasangan saringan. Setelah tanah mengering, pupuk ditebarkan ke dalam tambak. Pupuk berfungsi untuk menambahkan pakan alami (Achmad, 2011).

\section{d. Pemanenan Bandeng}

Menurut Jangkaru (1995), panen dapat dilakukan secara selektif maupun total. Pemanenan selektif artinya, pemanenan hanya dilakukan untuk individu ikan yang telah mencapai bobot sesuai dengan permintaan pasar. Caranya tambak dikeringkan terlebih dahulu kemudian untuk menangkap ikan digunakan jaring arad dan jaring insang. Panen selektif juga dimaksudkan agar ikan yang masih kecil dapat dipelihara kembali dan kesempatannya untuk tumbuh lebih cepat karena pesaingnya berkurang. 
Tingkat kelangsungan hidup (survival rate) yang dihasilkan dapat mencapai 80 - $90 \%$ dengan kualitas air yang optimal. Pemanenan merupakan kegiatan akhir dalam kegiatan pembesaran bandeng. Ukuran konsumsi (250 gr) menjadi patokan dilakukannya pemanenan. Cara pemanenan harus dilakukan secara hati-hati dan benar agar ikan tidak terluka karena dapat menurunkan harga jual ikan pada saat dijual. Panen bandeng konsumsi ini dilakukan pada pagi hari agar dapat langsung dipasarkan (Ahmad dan Yakob 1998).

\section{Aspek Finansial Kelayakan Usaha}

Berdasarkan hasil NPV para petani tersebut bernilai positif, hal ini menunjukkan usaha budidaya layak untuk diteruskan. Sesuai dengan pernyataan Gittinger (1986), suatu proyek atau usaha dapat dinyatakan layak jika nilai tunai (NPV) proyek lebih besar dari pada nol atau NPV sama dengan nol. Nilai NPV suatu proyek yang diterima jika nilai NPV positif maka investasi layak dan suatu proyek yang ditolak jika NPV negatif maka investasi ditolak. Nilai PP pada Desa Limbangan 0.34, Desa Mojo 0.98 dan Desa Pesantren 5.85. Nilai PP tersebut termasuk dalam kategori cepat dikarenakan pengembalian modal kurang dari 5 tahun. Menurut Umar (2003), tingkat pengembalian modal dikategorikan cepat jika nilai $\mathrm{PP}<5$ tahun dan lambat jika nilai PP $>5$ tahun. Semakin cepat dalam pengembalian biaya investasi sebuah proyek, semakin baik proyek tersebut karena semakin lancar perputaran modal (Yacob, 2003). Nilai B/C ratio pada masing-masing desa adalah 2.35 dan 4. Nilai tersebut menunjukkan bahwa masing-masing desa layak untuk dijalankan. Bila nilai $\mathrm{B} / \mathrm{C}>1$ berarti pendapatan cash dapat menutup biaya/pengeluaran cash dan investasi layak dilanjutkan (Murdifin dan Salim, 2003).

\section{KESIMPULAN DAN SARAN Kesimpulan}

Berdasarkan hasil penelitian yang telah dilakukan dapat diambil kesimpulan sebagai berikut:

Aspek teknis yang di lakukan di kecamatan Ulujami kabupaten Pemalang untuk budidaya ikan bandeng adalah pemilihan lokasi, penebaran benih, tempat pemeliharaan, pemanenan bandeng. Aspek finansial pembesaran ikan bandeng (Chanos-chanos) di Kecamatan Ulujami, Kabupaten Pemalang yaitu mengetahui biaya investasi, biaya operasional dan pendapatan. Kelayakan bisnis budidaya ikan bandeng di Kecamatan Ulujami, Kabupaten Pemalang dikatakan layak untuk dijalankan. Dengan nilai NPV 277.903.367 - 88.655.800/m2, B/C Ratio 0,21 1,66 dan Pyaback Periode 0,27 - 1,08.

\section{Saran}

Berdasarkan hasil penelitian saran yang dapat diberikan bahwa budidaya pada pembesaran ikan bandeng dengan metode semi intensif masih memiliki peluang untuk dikembangkan. Diharapkan para pembudidaya mampu mengelola dan mengembangkan potensi. Peran pemerintah diharapkan lebih aktif dalam memperhatikan dan memberi bantuan serta pendampingan kepada pembudidaya ikan sehingga budidaya bandeng semakin berkembang.

\section{UCAPAN TERIMA KASIH}

Terima kasih penulis ucapkan kepada Dinas Kelautan dan Perikanan Provinsi Jawa Tengah dan Kabupaten Pemalang, Badan Perencanaan dan Pembangunan Daerah (BAPPEDA) Provinsi Jawa Tengah dan Kabupaten Pemalang, Balai Karantina dan Kesehatan Ikan Provinsi Jawa Tengah yang telah memberikan doa, dukungan finansial dalam proses penelitian, terimakasih kepada bapak dan ibu Ghofur yang telah membantu dalam proses penelitian, Kantor Kepala Desa Pesantren dan Ketua RT/RW di Desa Pesantren yang telah memberikan ijin sehingga penelitian dapat berjalan, serta semua pihak yang telah mendukung saya untuk dapat melakukan penelitian dan membantu kelancaran dalam penelitian ini. 


\section{DAFTAR PUSTAKA}

Agnes, S. 2005. Analisis Kinerja Keuangan dan Perencanaan Keuangan Perusahaan. PT Gramedia Pustaka, Jakarta. 1-10 Hlm.

Ahmad, T. 1998. Budidaya Bandeng Secara Intensif. Maros: Penebar Swadaya. 47-52 Hlm.

Ahmad, T., Ratnawati Erna, and M. Jamil R. Yacob. 2000. Budidaya Bandeng Secara Intensif. Penebar Swadaya: Jakarta. $32 \mathrm{Hlm}$.

Afaf, N. 2004. Prospek Pengembangan Usaha Pembesaran Ikan Bandeng di Desa Muara, Kecamatan Cilawaya Wetan, Kabupaten Karawang, Provinsi Jawa Barat. Skripsi. Departemen Sosial Ekonomi Perikanan dan Kelautan. Fakultas Perikanan dan Kelautan. Institut Pertanian Bogor. Bogor.

Bambang, R. 2001. Dasar-Dasar Pembelanjaan Perusahaan, Edisi Keempat, Cetakan Ketujuh, BPFE Yogyakarta, Yogyakarta. $59 \mathrm{Hlm}$.

Cahyono, B. 2000. Budidaya Ikan Air Tawar: Ikan Gurami, Ikan Nila, Ikan Mas. Yogyakarta: Penerbit Kanisius. 80-92 Hlm.

Cresswell, J. W. 2008. Research Design Pendekatan Kualitatif, Kuantitatif dan Mixed. Ed III, Pustaka Pelajar Bandung, $678 \mathrm{hlm}$.

Dyckman, Thomas R., Roland E.D., Charles J.D. 2000. Akuntansi Intermediate. Edisi Ketiga. Jilid 1. Erlangga: Jakarta. 60-87 Hlm.

Garcia, L.M.B. 1990. Fisheries Biology of Milkfish (Chanos chanos Forskal). Proceedins of the Regional Workshop on Milkfish Culture Development in the South Pacific tarawa, Kribati, 21-25 November 1988.

Gittinger, J. P. 1986. Analisa Ekonomi Proyek-Proyek Pertanian. Ed. II, UI Press, Jakarta. 11-20 Hlm.

Ghufran, M. 1997. Budidaya Kepiting dan Ikan Bandeng di Tambak Sistem Polikultur. Semarang : Dahara Prize. $75 \mathrm{Hlm}$.

Gordon, M.S, and Hong, L.Q. 1986. Biology of Chanos chanos. In: Lee CS, Gordon MS, Watanabe WO. Editor. Aquaculture of Milkfish (Chanos chanos): State of the Art. The Oceanic Institute Makapuu Point Waimanolo, Hawai, hlm 1-33.

Hadie, W dan S. Jatna. 1986. Teknik Budidaya Bandeng. Bhantara Karya Aksara. Jakarta. 57 Hlm.

Hendriksen, Eldon S. 2002. Teori Akuntansi, Edisi Keempat, Jilid I. Penerbit Erlangga. Jakarta. 44 Hlm.

Husnan, S. dan Muhammad, S. 2005. Studi Kelayakan Proyek. Edisi Keempat. Yogyakarta, Unit Penerbitan dan Percetakan AMP YKPN. 23 Hlm.

Kasmir dan Jakfar. 2008. Studi Kelayakan Bisnis, Edisi 2. Kencana Prenada Media Group, Jakarta. 1-17 Hlm.

Kordi, G.M. 2009. Sukses Memproduksi Bandeng Super untuk Umpan, Ekspor, dan Indukan. Andi, Jakarta, 148 Hlm.

Kordi, G.M. 2007. Pembenihan Bandeng. PT. Perca. Jakarta.

Lukstadt, C. and Reiti, T. 2002. Investigetion on Feeding Behaviour of Juvenile Milkfish (Chanos chanos Forskal) in Brackishwater Lagoons on South Tarawa, Kribati. Verhandlungen der Gesellschaft Fur Ichthyologie Band 3, p : 37-38.

Mardalis. 2008. Metode Penelitian Suatu Pendekatan Proposal. PT Bumi Aksara, Jakarta, 108 Hlm.

Mimit et. al. 2006. Potensi Dan Peluang Bisnis Usaha Unggulan Ikan Gurami dan Nila. Bahtera Press : Malang.

Moleong, Lexy J. 2007. Metodologi Penelitian Kualitatif. Penerbit PT Remaja Rosdakarya Offset: Bandung. 89 Hlm

Nurmalina, R., Sarianti T., dan Karyadi, A. 2009. Studi Kelayakan Bisnis. Departemen Agribisnis FEM IPB, Bogor. $84 \mathrm{Hlm}$.

Nurmalina, R., Sarianti T., dan Karyadi, A. 2010. Studi Kelayakan Bisnis. Departemen Agribisnis FEM IPB, Bogor. $70 \mathrm{Hlm}$.

Nontji, A. 2006. Tiada Kehidupan di Bumi Tanpa Keberadaan Plankton. Lembaga Ilmu Pengetahuan Indonesia. Pusat Penelitian Oseanografi. Jakarta. 46-55 Hlm

Omtimo. 2011. Padat Penebaran dan Pengelolaan Budidaya Perikanan. www.omtimo.org/penebaran-danpengelolaan-budidaya-perikanan.html (18 Juni 2014).

Paul R. Krugman dan Maurice Obsfeld. 1994. Ekonomi Internasional, Teori dan Kebijakan. Jakarta. PT. Raja Grafindo Persada.

Prof. Dr. Ahmad Rodoni, Herni Ali,HT,SE,MM. (2010). Manajemen Keuangan. Jakarta: Mitra Wacana Media. 55-75 Hlm.

Raja Adri Satriawan Surya. 2012. Akuntansi Keuangan Versi IFRS. Edisi Pertama. Yogyakarta: Graha Ilmu. 1-20 Hlm.

Ross, Stephen A., dkk. 2008. Corporate Finance Fundamentals. Buku 1 Edisi 8. New York: McGraw-Hill. 80 Hlm. Santiago, C.B. 1986. Nutrition and Feeds. In: Lee C.S \& Gordon M.S, Watanabe W.O. Editor. Aquaculture of Milkfish (Chanos chanos): State Of The Art. The Oceanic Institute Makapuu Point Waimanalo, Hawai. 181-199 p.

Soeseno, 1982. Dasar Perikanan Umum. Jasa Guna, Jakarta.

Tristian. 2011. Budidaya Ikan Bandeng. Pusat Penyuluhan, Kementerian Kelautan Perikanan. Jakarta. 77 Hlm.

Yakob, M.J.R., dan T. Ahmad, 1997. Budidaya Bandeng Intensif. Makalah yang disajikan pada acara ekspose hasil penelitian perikanan pantai Maros. 22 Oktober 1997. 